\title{
TEMPERATURE ANALYSIS OVER EGYPT
}

\author{
M. M. Eid ${ }^{1}$, Elsaied H. Gad ${ }^{1}$, and H. Abdel Basset ${ }^{1}$ \\ ${ }^{1}$ Astronomy and Meteorology Department, Faculty of Science, Al-Azhar University, Cairo, Egypt. \\ Corresponding author:mm_eid2000@yahoo.com; elsaied.gad@azhar.edu.eg; heshmatm@yahoo.com
}

\begin{abstract}
In this study monthly, seasonal and annual values of temperature have been analyzed over Egypt during the period 1960-2016. It is found that the temperature is a function of latitudes where the values of temperature increase gradually from north to south. The trend analysis illustrates that there is a significant increase in seasonal and annual values of temperature over Egypt. The annual wave dominates at all stations; its amplitude for the northern stations is smaller than those for the southern stations. The analysis of the spatial distribution of the monthly average of temperature $(1960$ - 2016) for each month of the year has been made. It is found that Latitudinal gradients in temperature are strong in winter and spring seasons with particular increase over the north of Egypt due to the effect of mid-latitude travelling depressions from west to east over Egypt. The climatological distribution of temperature throughout the months of the year reflects the effect of meteorological factors and pressure systems affecting the weather and climate in the study area. The warmest areas in summer are the middle and the south eastern parts of Egypt.
\end{abstract}

Keywords: surface air temperature series; Annual cycle; Trend analysis; Climate variability.

\section{INTRODUCTION}

Air temperature is one of the most important components of climate, due to its significant contribution to surface- atmosphere processes and interactions [1]. Changes in surface air temperature can be of particular interest in a variety of environmental, ecological, hydrological and societal applications hydrological, environmental, and societal applications. Over the last few decades, air temperature variability and changes have received much attention especially with the global surface temperature experiencing an average increase of roughly $0.7{ }^{\circ} \mathrm{C}$ over the second half of the 20th century [2-4].

During the last decades, numerous studies have investigated the temporal variability of temperature at various temporal and spatial scales, confirming a significant warming in the Middle East and North Africa regions [5-7]. There have also been many regionalized studies; reflect the larger scale trend in temperature such as for Egypt [8-12], Saudi Arabia [13], Libya [11], and Morocco [14].

There has been continuous attention in studying extreme temperature events that have occurred on the Mediterranean [15-17], the Middle East [18], and the Arab region [19] to also include global studies [20, 21]. In the Middle East and North Africa regions, some studies have attempted to identify horizontal and temporal changes in temperature extremes at the country level, including Iran [22], Iraq [23], Saudi Arabia [13,24], Jordan [25] and Morocco [14]. For example, [23] indicated that mean temperature in Iraq has increased during the period 19652015 faster than the global temperature rise, leading to an increase in warm extremes (warm nights) and a decrease in cold extremes (cold days). In their assessment of changes in temperature extremes over Morocco, [14] reported that changes in cold extremes are larger than those of warm events.

The increase in temperature has impacts such as: increased incidence and severity of heat-waves, droughts [26]. Over Egypt, there has been a number of mega heat waves in the last decade, particularly the record-breaking summers of 2010, 2011, 2012, 2015 and 2018, which caused the loss of life and severe economic damage to many sectors (e.g. agriculture, energy, water resources) [27-29]. This work aims to study the temperature analysis and variability over Egypt. 


\section{DATA}

\subsection{Egypt meteorological stations data}

In this paper, monthly temperature records are compiled by 30 stations from the Egyptian Meteorological Authority (EMA). The stations under study are distributed all over Egypt, although the spatial density is quite uneven in some parts of the country.

Table 1: The name, position and elevation for each selected Egypt stations.

\begin{tabular}{|c|c|c|c|c|c|}
\hline No & Name Station & $\begin{array}{l}\text { Lat } \\
\left({ }^{\mathbf{0} N}\right)\end{array}$ & $\begin{array}{c}\text { Long } \\
\left({ }^{\circ} \mathbf{E}\right)\end{array}$ & $\begin{array}{c}\text { Elevation } \\
\text { (m) }\end{array}$ & $\begin{array}{c}\text { Mean Temp } \\
\left({ }^{\circ} \mathbf{C}\right)\end{array}$ \\
\hline 1 & Baltim & 31.55 & 31.10 & 2 & $1960-2016$ \\
\hline 2 & Port Said & 31.28 & 32.23 & 6 & $1960--2016$ \\
\hline 3 & Mersa-Matruh & 31.20 & 27.13 & 28 & $1960-2016$ \\
\hline 4 & Alexandria & 31.11 & 29.56 & 7.0 & $1960-2016$ \\
\hline 5 & El Arish AP & 31.05 & 33.49 & 31 & $1960--2016$ \\
\hline 6 & Tanta & 30.78 & 31.00 & 8.3 & $1960-2016$ \\
\hline 7 & Tahrir & 30.65 & 30.69 & 16 & $1960-2016$ \\
\hline 8 & Ismailia AP & 30.60 & 32.25 & 13 & $1960-2016$ \\
\hline 9 & Dabaa & 30.56 & 28.26 & 18 & $1960-2016$ \\
\hline 10 & Wadi-Elnatroon & 30.40 & 30.30 & 1 & $1960-2016$ \\
\hline 11 & Cairo AP & 30.13 & 31.40 & 74 & $1960-2016$ \\
\hline 12 & El-Suez & 29.94 & 32.55 & 4.0 & $1960-2016$ \\
\hline 13 & Helwan & 29.87 & 31.33 & 141 & $1960-2016$ \\
\hline 14 & Ras-Sedr & 29.58 & 32.72 & 16.0 & $1960-2016$ \\
\hline 15 & Ras-ELnakab & 29.34 & 34.45 & 633 & $1960-2016$ \\
\hline 16 & BeniSuef & 29.12 & 31.10 & 36.6 & $1960-2016$ \\
\hline 17 & Siwa & 29.20 & 25.48 & -13.5 & $1960-2016$ \\
\hline 18 & Baharia & 28.20 & 28.54 & 130.0 & $1960-2016$ \\
\hline 19 & El-Tor & 28.20 & 33.64 & 14 & $1960--2016$ \\
\hline 20 & Minya & 28.05 & 30.44 & 41 & $1960-2016$ \\
\hline 21 & Sharm El-Sheikh & 27.97 & 34.38 & 51 & $1960-2016$ \\
\hline 22 & Hurghada & 27.28 & 33.46 & 7 & $1960-2016$ \\
\hline 23 & Hurghada AP & 27.11 & 33.48 & 14 & $1960--2016$ \\
\hline 24 & Farafra & 27.03 & 27.59 & 91.8 & $1960-2016$ \\
\hline 25 & Asyut AP & 27.03 & 31.00 & 70.0 & $1960-2016$ \\
\hline 26 & Sohag & 26.36 & 31.47 & 40.5 & $1960-2016$ \\
\hline 27 & Luxor & 25.40 & 32.42 & 99 & $1960-2016$ \\
\hline 28 & Al-Kharga (Ag) & 25.28 & 30.32 & 73 & $1960-2016$ \\
\hline 29 & Al-Dakhla & 25.27 & 29.00 & 112 & $1960-2016$ \\
\hline 30 & Aswan & 23.58 & 32.47 & 195 & $1960-2016$ \\
\hline
\end{tabular}

Table 1 and Figure 1 illustrate the location, elevation, and the period for each selected meteorological station.

Homogeneity of the data: Bartlett test will be used to examine the homogeneity of the data when Gaussian distribution of values is considered. The method is simply accomplished by dividing the considered time series into $K$ equal sub-period $(k \geq 2)$. The sample variance is calculated using the following relation [30].

$$
S_{k}^{2}=\frac{1}{n}\left(\sum x_{i}^{2}-\frac{1}{n}\left(\sum x_{i}\right)^{2}\right)
$$

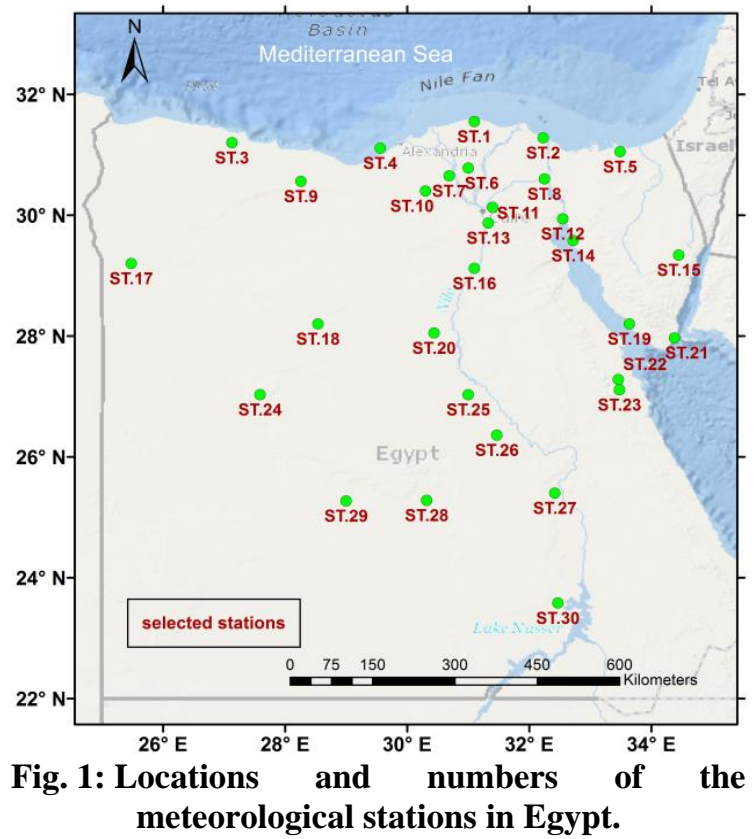

Where the summations range over the $n$ values of the series, $\Sigma \mathrm{i}$ in the sub-period $\mathrm{K}$. The estimated ratio between the maximum and minimum values $\left(S_{\max }^{2} / S_{\min }^{2}\right)$ is compared with the values given in table 1 of [31] to determine the percentage value of significance.

\subsection{Monthly mean air temperature (NCEP Reanalysis)}

To understand the spatial distribution of temperature during the months of the year, we use monthly mean gridded temperature dataset from the National Centers for Environmental Prediction (NCEP) and National Center for Atmospheric Research (NCAR) Reanalysis (hereafter, NNR) are used. The NNR is created by assimilating observed weather data (e.g. temperature) using state-of-the-art global climate-forecasting model that produces interpolated grid output on a $2.5^{\circ} \mathrm{X} 2.5^{\circ}$ latitude-longitude grid, with the application of a high level of quality control. The firstgeneration of NNR is from 1948, which is close to real time $[32,33]$.

The NNR temperature gridded dataset [32] used in this study has been extracted for the Egyptian region covering the period 19602016. The simulation of the NNR temperature gridded dataset is strongly influenced by observed data. Hence, these data are the most reliable in terms of time $[32,33]$. 


\section{RESULTS AND DISCUSSION}

\subsection{Homogeneity of the data}

Studies on data homogeneity are essential in climatology. Homogeneity is manifested differently in different climatic elements.

Table 2: Bartlet test (short- cut) result for the annual, winter, spring, summer and autumn of the temperature of Egypt stations ( $n$ is the number of terms in each sub-period $k$, and $k$ is the number of the sub-period).

\begin{tabular}{|c|c|c|c|c|c|c|c|c|}
\hline \multirow{2}{*}{$\begin{array}{c}\text { Station } \\
\text { name }\end{array}$} & \multirow[b]{2}{*}{$\mathbf{n}$} & \multirow[b]{2}{*}{$\mathbf{k}$} & \multirow{2}{*}{$\begin{array}{c}95 \% \\
\text { Significant } \\
\text { point }\end{array}$} & \multicolumn{5}{|c|}{ Homogeneity (Temperature) } \\
\hline & & & & Annual & Win & Spr & Sum & Aut \\
\hline Baltim & 19 & 3 & 3.24 & 1.32 & 7.53 & 8.74 & 0.97 & 0.49 \\
\hline Port Said & 19 & 3 & 3.24 & 0.95 & 3.35 & 4.41 & 1.34 & 0.47 \\
\hline $\begin{array}{l}\text { Mersa- } \\
\text { Matruh }\end{array}$ & 28 & 2 & 2.20 & 0.61 & 1.84 & 1.10 & 0.39 & 0.63 \\
\hline Alexandria & 19 & 3 & 3.24 & 1.60 & 5.46 & 9.45 & 1.28 & 0.89 \\
\hline El Arish AP & 28 & 2 & 2.20 & 0.51 & 0.66 & 1.13 & 1.98 & 0.69 \\
\hline Tanta & 19 & 3 & 3.24 & 0.25 & 1.90 & 5.14 & 1.31 & 0.18 \\
\hline Tahrir & 19 & 3 & 3.24 & 0.05 & 1.33 & 0.54 & 0.03 & 0.09 \\
\hline Ismailia AP & 19 & 3 & 3.24 & 3.14 & 3.60 & 5.00 & 4.18 & 1.05 \\
\hline Dabaa & 19 & 3 & 3.24 & 0.80 & 0.33 & 0.94 & 1.73 & 0.44 \\
\hline $\begin{array}{l}\text { Wadi El- } \\
\text { natroun }\end{array}$ & 28 & 2 & 2.20 & 2.14 & 3.28 & 2.10 & 2.21 & 0.66 \\
\hline Cairo AP & 19 & 3 & 3.24 & 0.09 & 2.60 & 1.50 & 0.70 & 0.15 \\
\hline El-Suez & 19 & 3 & 3.24 & 0.16 & 1.01 & 4.75 & 0.49 & 0.16 \\
\hline Helwan & 19 & 3 & 3.24 & 0.33 & 3.84 & 5.56 & 0.21 & 0.23 \\
\hline Ras-Sedr & 19 & 3 & 3.24 & 1.03 & 1.76 & 2.50 & 1.18 & 0.28 \\
\hline $\begin{array}{l}\text { Ras - } \\
\text { Elnakab }\end{array}$ & 19 & 3 & 3.24 & 0.19 & 0.92 & 3.22 & 0.44 & 0.13 \\
\hline Beni Suef & 19 & 3 & 3.24 & 0.01 & 0.02 & 0.05 & 1.61 & 0.26 \\
\hline Siwa & 28 & 2 & 2.20 & 0.59 & 2.21 & 2.22 & 0.59 & 0.39 \\
\hline Baharia & 28 & 2 & 2.20 & 1.56 & 1.66 & 1.56 & 1.64 & 1.26 \\
\hline El-Tor & 28 & 2 & 2.20 & 0.45 & 0.14 & 0.49 & 1.29 & 0.45 \\
\hline Minya & 19 & 3 & 3.24 & 0.06 & 1.22 & 1.39 & 0.42 & 0.21 \\
\hline $\begin{array}{l}\text { Sharm El- } \\
\text { Sheikh }\end{array}$ & 19 & 3 & 3.24 & 0.12 & 0.97 & 0.55 & 0.15 & 0.18 \\
\hline Hurghada & 28 & 2 & 2.20 & 0.87 & 0.96 & 1.38 & 1.39 & 0.70 \\
\hline $\begin{array}{l}\text { Hurghada } \\
\text { AP }\end{array}$ & 28 & 2 & 2.20 & 1.86 & 2.76 & 1.80 & 2.16 & 1.04 \\
\hline Farafra & 28 & 2 & 2.20 & 0.24 & 0.20 & 0.86 & 1.00 & 0.40 \\
\hline Asyut AP & 19 & 3 & 3.24 & 2.54 & 2.63 & 3.26 & 9.43 & 1.79 \\
\hline Souhag & 28 & 2 & 2.20 & 0.27 & 0.50 & 0.75 & 0.33 & 0.36 \\
\hline Luxor & 19 & 3 & 3.24 & 0.18 & 2.66 & 1.46 & 0.31 & 0.08 \\
\hline Kharga (Ag) & 19 & 3 & 3.24 & 0.07 & 1.28 & 0.63 & 1.06 & 0.07 \\
\hline Dakhla & 28 & 2 & 2.20 & 0.51 & 0.88 & 0.58 & 1.64 & 0.76 \\
\hline Aswan & 19 & 3 & 3.24 & 0.81 & 5.00 & 2.19 & 1.11 & 0.21 \\
\hline
\end{tabular}

The values of climatic elements could be the method for estimating daily and monthly averages. Artificial lakes and reservoirs and other man-made changes of local environment produce sources of inhomogeneity in historical records of climatic data.

Homogeneity of the annual and seasonal temperature time series over the cities of Egypt has been examined by means of Bartlett test Table (2) shows the results from the Bartlet test (short-cut) for annual, winter, spring, summer and autumn temperature. It indicates that mean annual temperature series at all stations are homogeneous. Using the ratio (Mitchell et al. 1966) the data show homogeneity at 5\% significance level in the autumn also at all stations. The summer temperature is also homogeneous at all stations except Ismailia AP and Asyut AP. The null hypothesis of homogeneity is rejected also for Baltim, Port Said, Alexandria, Tanta, Ismailia AP, El-Suez, Helwan and Asyut AP during spring season. The null hypothesis of homogeneity is rejected also for Baltim, Port Said, Alexandria, Ismailia AP, Wadi-Elnatroun, Helwan, Hurguada AP, Asyut AP and Aswan during winter season.

\subsection{Annual cycle}

The annual cycle is the dominant component for many climate variables outside the tropics and the most prominent climate oscillation. Surface air temperature (SAT), under a changing climate in contrast to the numerous studies focusing on long-term global or regional warming [34]. This is partly because the annual cycle of a climate variable, which is traditionally assumed repetitive from year to year and estimated by averaging the values of that variable for the same day/month over a period of several years, is frequently removed in studies concerning climate variability or changes.

However, inter-annual variations and changes in the annual cycle can be seen in many climate time series. and an increasing number of studies since the 1990s have shown that climate change is not only reflected in the change in the annual mean of a climate variable but also in the long-term change in the amplitude and phase of its annual cycle (the yearly period component). Changes in the 
amplitude of the annual cycle of SAT could affect its trend estimation [35], and it has been suggested that these changes have be taken into account in temperature reconstructions [36]. Figure 2 shows that the annual cycle of mean temperature for the period (1960-2016) for stations Alexandria, Cairo, Ras-Sedr, El-Tor, Hurghada, Souhag, Luxor and Aswan as a sample of available stations (30 stations ) over Egypt.

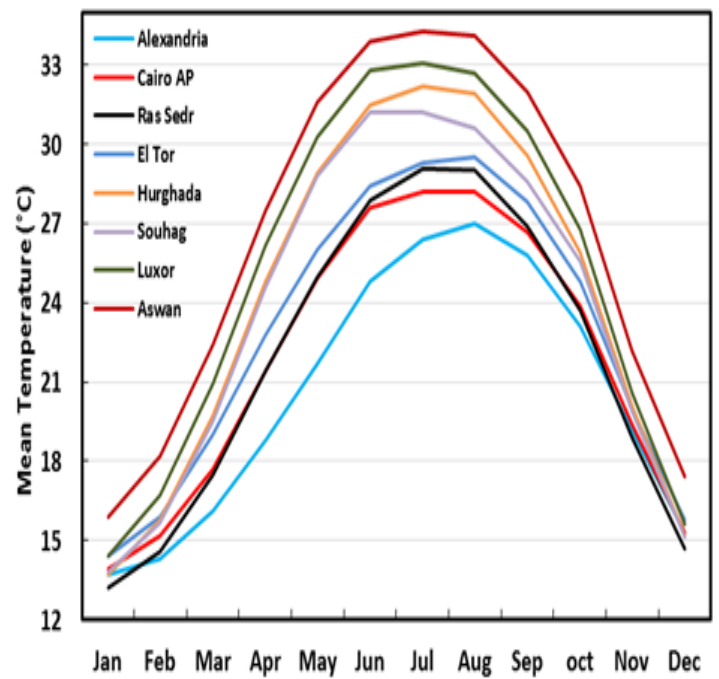

Fig. 2: Mean inter-annual variability of mean temperature for the period (1960-2016) for stations Alexandria, Cairo, Ras Sedr, El-Tor, Hurghada, Souhag, Luxor and Aswan.

As in figure 2 which shows that high amplitude occurs at Aswan station which lies in south Egypt while the low amplitude occurs at Alexandria station which lies in north Egypt. Also, we find that the amplitude increases gradually from North Egypt to South Egypt, this indicates to the northern stations have the lower amplitude while the southern stations have the higher amplitude. Also, it is clear that the coldest months are December, January and February where mean temperature increases gradually from March month until reaches to its peak in July and August with an average air temperature of $34^{\circ} \mathrm{C}$ at Aswan. Then the mean temperature decreases gradually till December month.

\subsection{Monthly analysis}

In this section we will discuss the behavior of the monthly values of temperature of our stations during the period 1960-2016. Figures $3 \mathrm{a}$ and $3 \mathrm{~b}$ show the monthly values of temperature for 8 stations as a sample from 30 stations. The stations were arranged from north to south. The analysis of the monthly time series for different stations leads to the following main results:

1- The annual wave is the dominant wave at all stations. The amplitude of the annual wave at the northern stations is smaller than those in the southern stations. Generally, temperature values also increase from north to south.

2- The lowest values of temperature occur more in the northern stations and they increase gradually from north to south. This can be seen by comparing the time series of Alexandria (3a) with the corresponding time series of Aswan (3b).
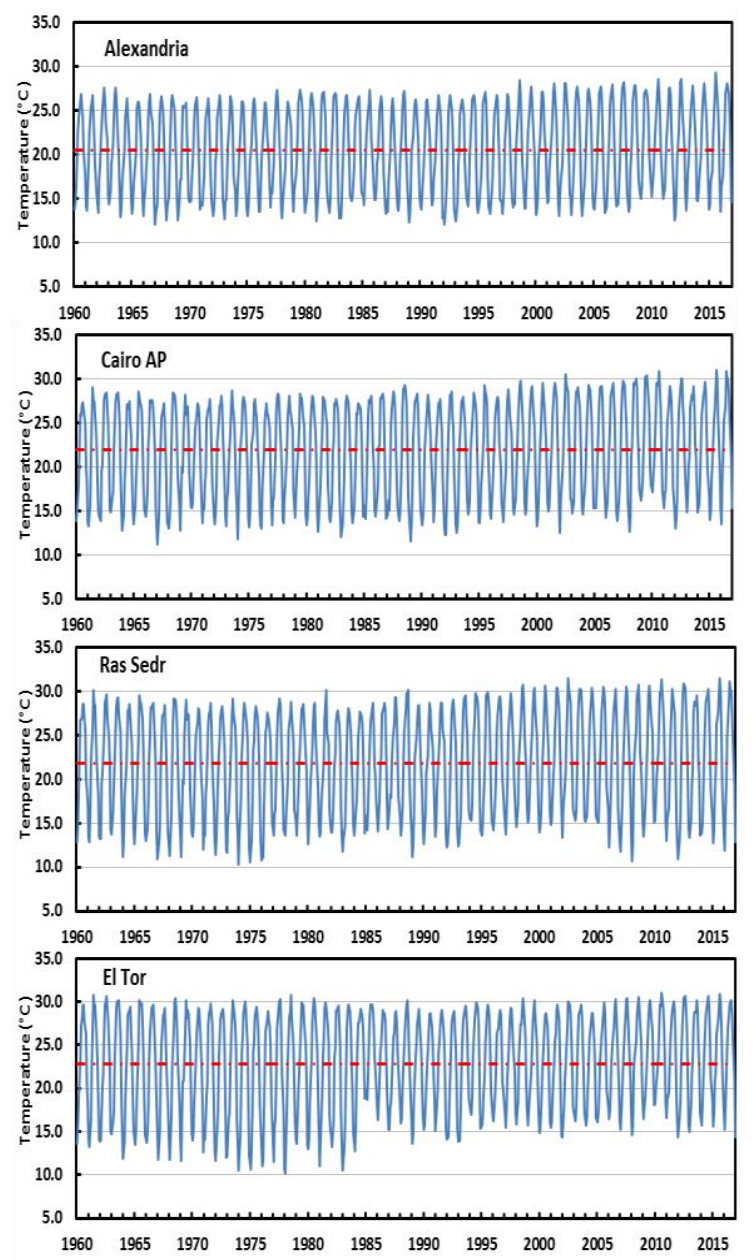

Fig. 3a: The monthly values of mean temperature during the available period at the stations Alexandria, Cairo, Ras Sedr and El-Tor.

3-The maximum of monthly mean temperature value over Egypt stations is $37.5^{\circ} \mathrm{C}$, it occurs at Aswan in the year 2015, while the minimum 
of mean monthly temperature value is $8.3{ }^{\circ} \mathrm{C}$, it appears at Ras-Elnakab in the year 2002 .

4 - Positive trends have a persistent feature and occur at all stations.
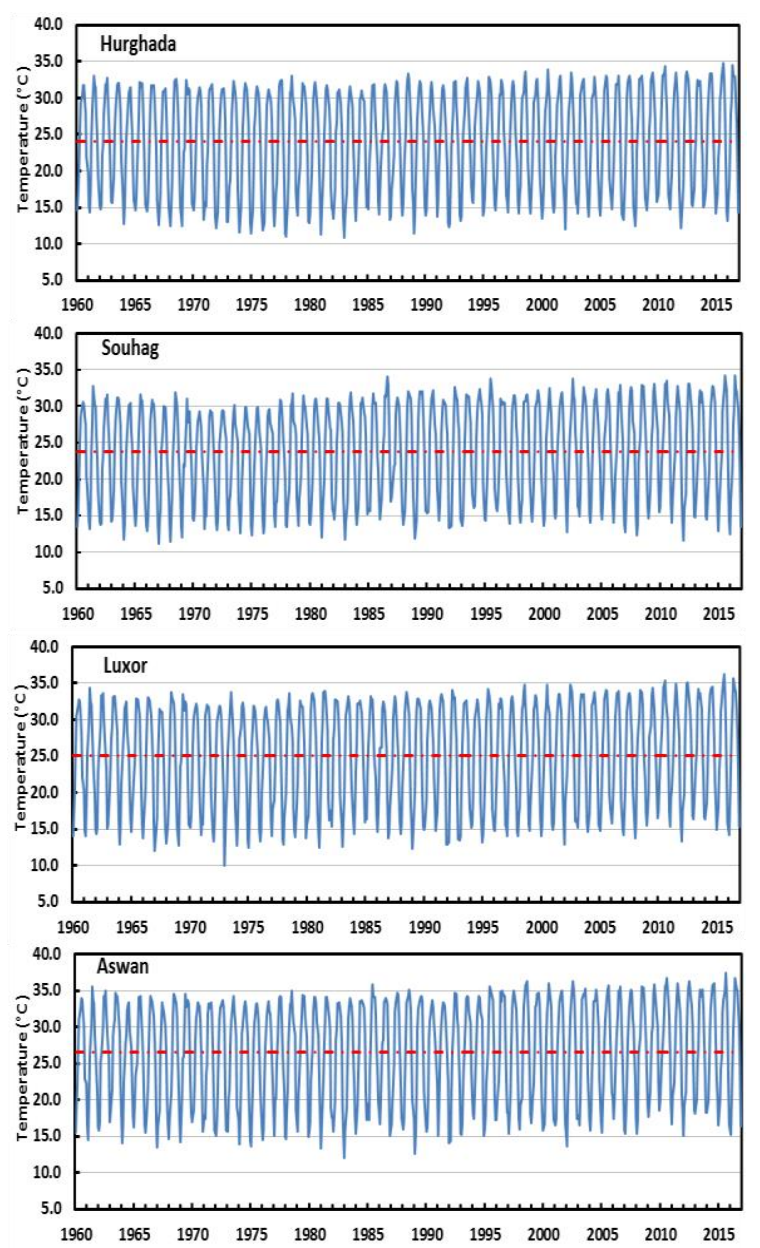

Fig. 3b: The monthly mean temperature during the available period at Hurghada, Souhag, Luxor and Aswan stations.

5- The monthly mean temperature values of the northern stations time series range nearly from $10{ }^{\circ} \mathrm{C}$ to $30^{\circ} \mathrm{C}$, while for the southern stations it ranges from $10{ }^{\circ} \mathrm{C}$ to $35^{\circ} \mathrm{C}$.

6- A relatively large number of mean temperature minima occurred at most stations in the years 1967, 1983 and 1989, while a relatively large number of mean temperature maxima occurred at most stations in the years 2010, 2014 and 2016.

7- The lowest amplitude of the annual wave occurs at Alexandria station, while the highest amplitude occurs at Aswan station.
In this section also, we will show and discuss the values of monthly mean temperature averaged along the period (19602016) for each month from December to May over Egypt stations. For figures $4 \mathrm{a}-4 \mathrm{~b}$, we will show the results here starting from the northern to the southern stations. It is clear that the minimum values of mean temperature appear during the winter months (Dec, Jan and Feb). The maximum values of mean temperature at each station appear in the summer months (Jun, Jul and Aug). It can be seen that the temperature values start to increase gradually from March to reach a maximum in July then decrease gradually to reach a minimum in December. Also, it is interesting to note that the temperature values are a function of latitude. This can be seen from the temperature values from north to south for each month. The temperature difference between northern and southern part of Egypt reaches $5{ }^{\circ} \mathrm{C}$ in January, while it reaches to $9{ }^{\circ} \mathrm{C}$ in July. Therefore, it can be said that the difference in summer season is greater than the difference in winter season. The reason for the displacement of the thermal depressions toward North in the summer season, which significantly heats the land but, north of Egypt, is affected by Mediterranean Sea, so the difference in average temperatures is relatively large, While in the winter season, the land is cooled down significantly, where the coastal region is affected by sea surface temperature of Mediterranean Sea, so that the difference is small in winter season. Also, the annual cycle (months of year) for north Egypt in summer season have maximum temperature in August month and minimum temperature occurs in January month. Also, in summer season the annual cycle for south Egypt have maximum temperature in July month and minimum temperature in January month. 

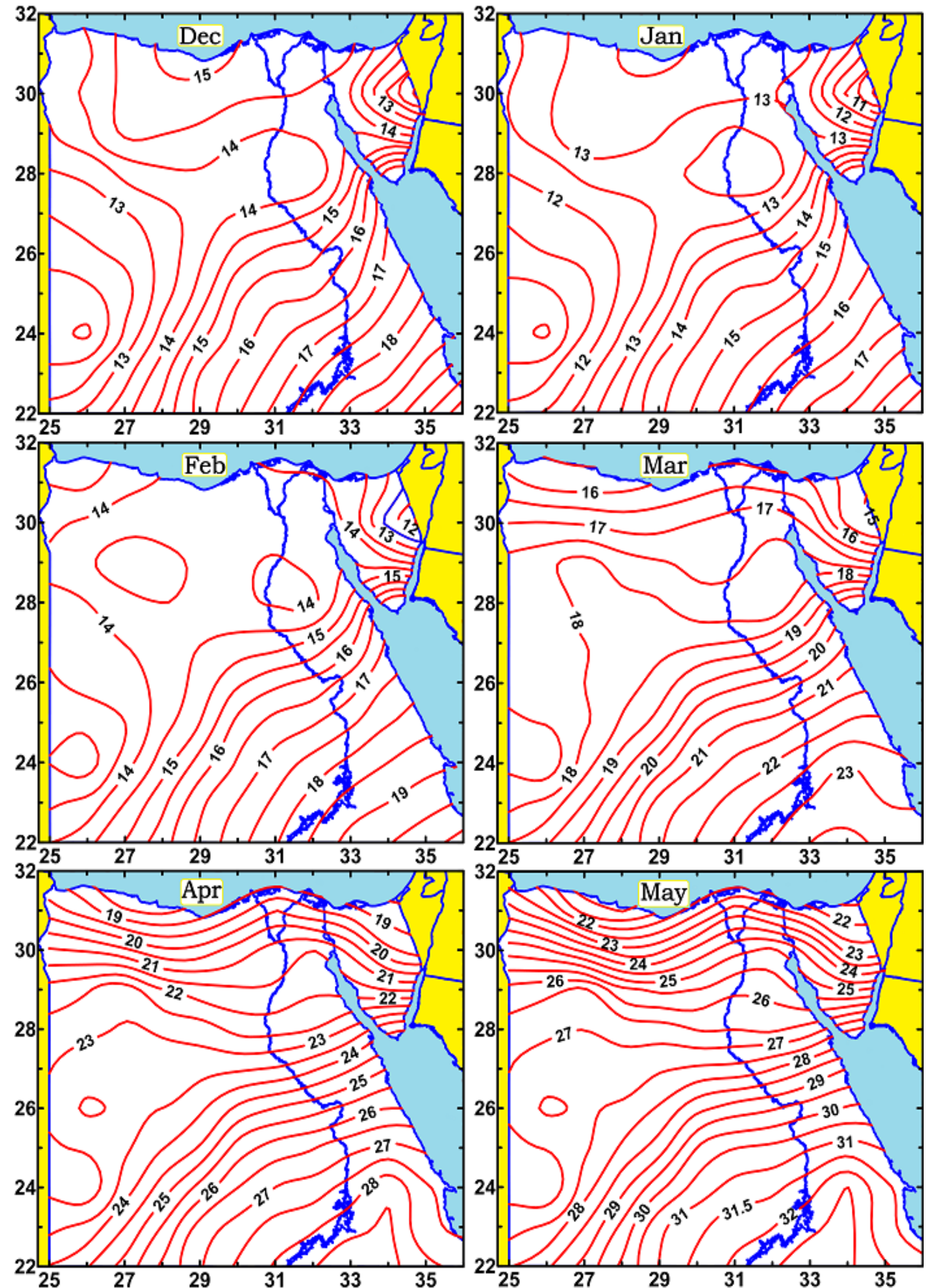

Fig. 4a: The values of monthly mean temperature averaged along the period (1960-2016) for each month from December to May at all the Egyptian stations. 

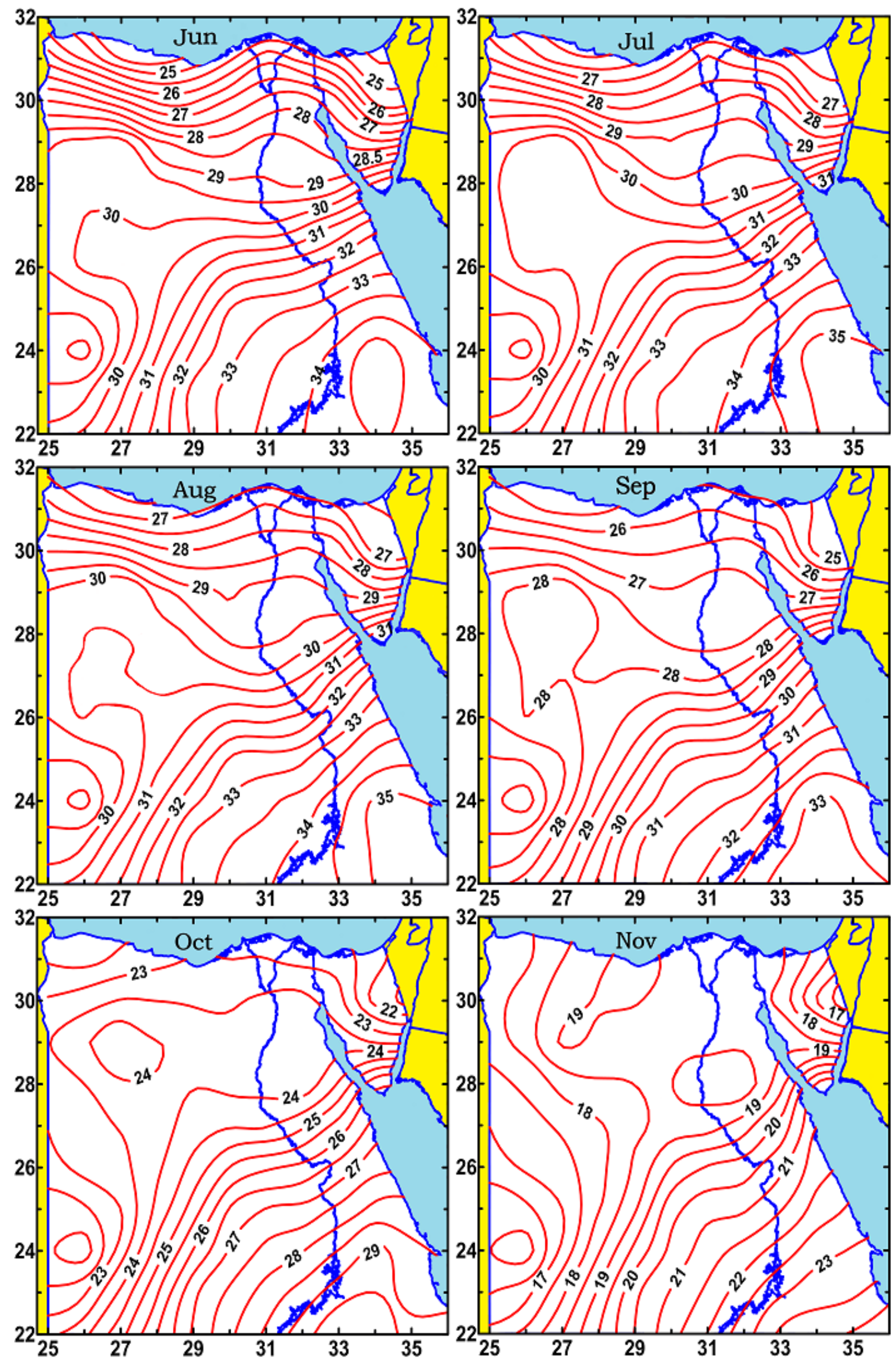

Fig. 4b: The values of monthly mean temperature averaged along the period (1960-2016) for each month from June to November at all the Egyptian stations. 


\subsection{Seasonal and annual analysis.}

In the climatic seasons and annual we observe a different tendency of changes in air temperature. Figure 5 shows the average of the seasonal and annual air temperature distribution over the period 1960-2016 over Egypt. Figure 5 shows that the maximum values of mean
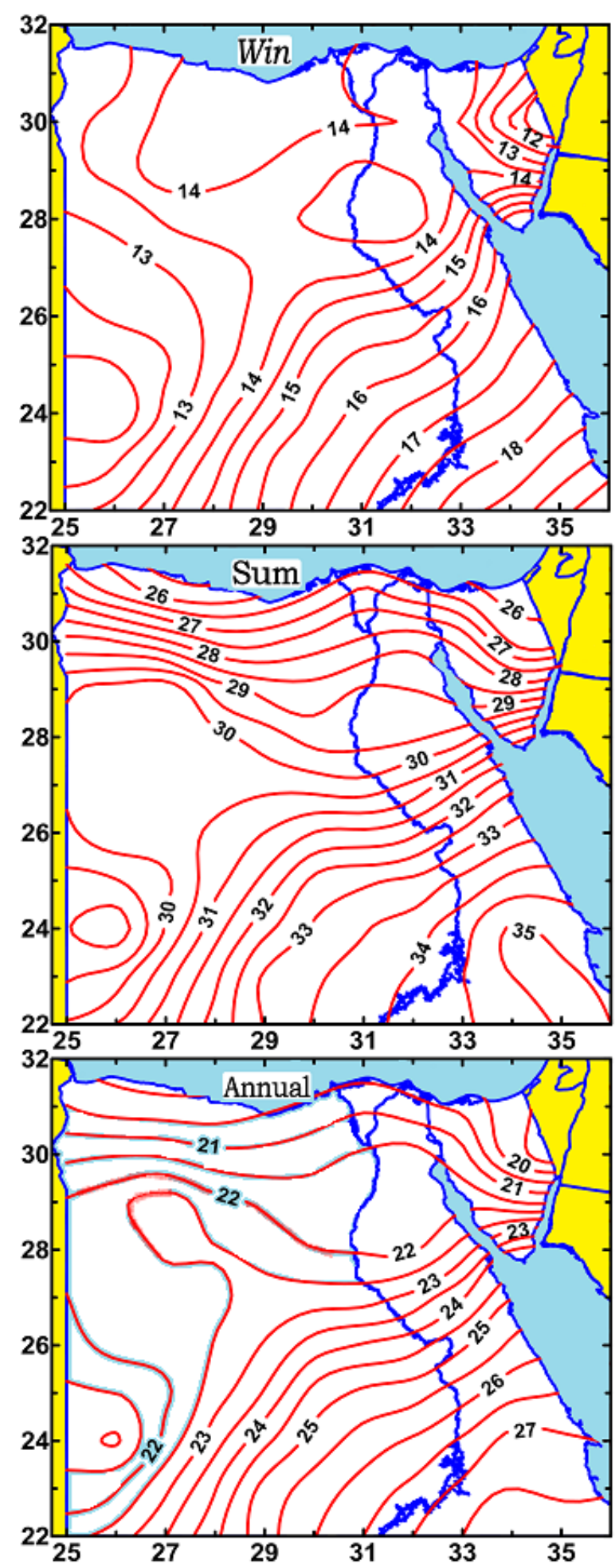

temperature occur in summer season while the lowest values of temperature occur in winter season. The second maximum values of mean temperature occur in autumn season. Also, the seasonal and annual values of mean temperature is a function of latitude and increase gradually from north to south of Egypt.
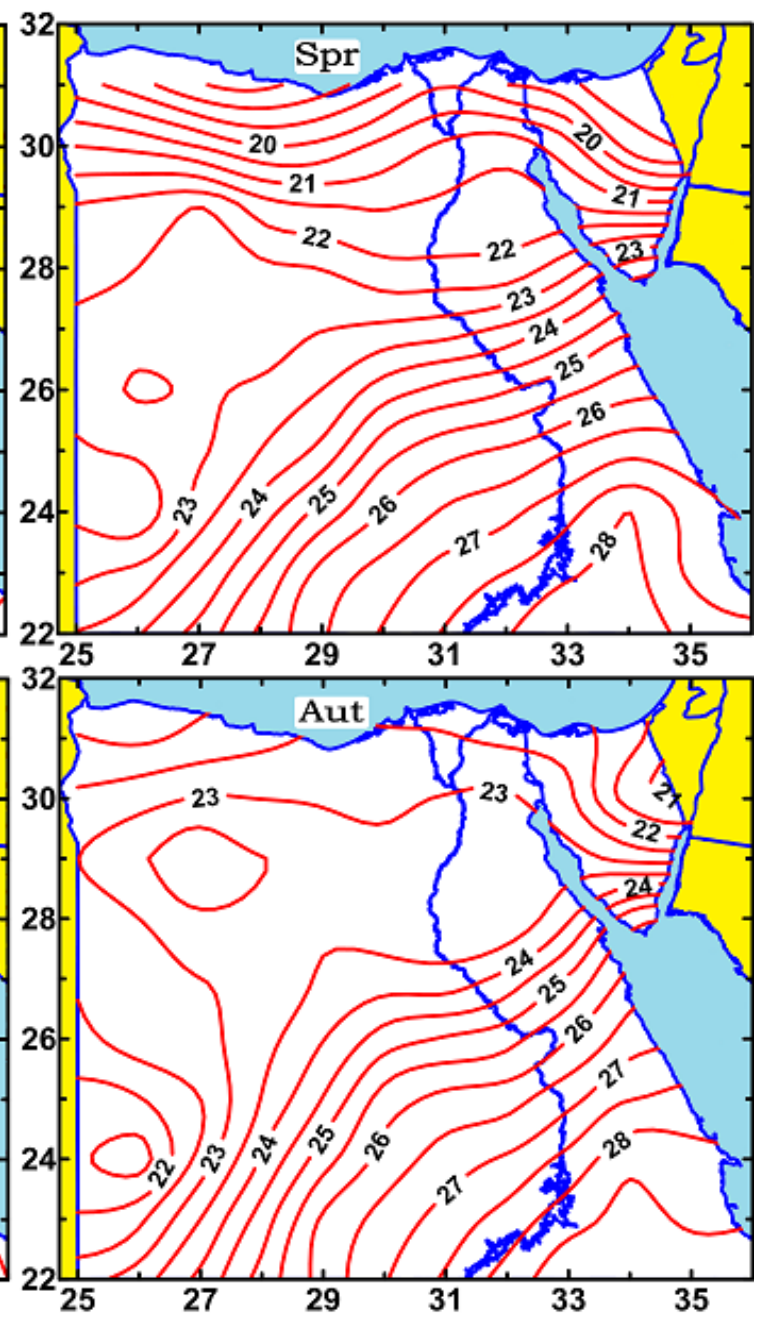

Fig. 5: Seasonal and annual temperature averaged for the period $(1960-2016)$ at Egyptian stations. 
In winter (DJF), highest mean temperature up to $18^{\circ} \mathrm{C}$ is found over the south east of Egypt. Lowest mean temperature up to $12^{\circ} \mathrm{C}$ is found over the north east of Sinai. Mean temperatures increase from around $13^{\circ} \mathrm{C}$ on the Mediterranean coastline to around $13.5^{\circ} \mathrm{C}$ and increase from $14^{\circ} \mathrm{C}$ to $19^{\circ} \mathrm{C}$ on the Red Sea coastline. The difference between the values of mean temperature in the north and the south of Egypt reaches about $5^{\circ} \mathrm{C}$ in winter. In Spring (MAM), highest mean temperature up to $28^{\circ} \mathrm{C}$ is found over the south east of Egypt. Mean temperatures have a large gradient along Mediterranean and Red Sea coastlines, about $21^{\circ} \mathrm{C}$ at Cairo and $27^{\circ} \mathrm{C}$ south at Aswan. The difference between the values of mean temperature in the north and the south of Egypt reaches $8^{\circ} \mathrm{C}$ in spring. In Summer (JJA), highest mean temperature up to $35^{\circ} \mathrm{C}$ is found over the south east of Egypt. Mean temperatures increase around $26^{\circ} \mathrm{C}$ on the Mediterranean coastline and gradient about $6^{\circ} \mathrm{C}$ along the Red Sea coastline. The difference between the values of mean temperature in the north and the south of Egypt reaches about $9^{\circ} \mathrm{C}$ in summer. In Autumn (SON), highest mean temperature up to $28.5^{\circ} \mathrm{C}$ is found over the south east of Egypt. Mean temperature increase around $22.5^{\circ} \mathrm{C}$ on the Mediterranean coastline and gradient about $5^{\circ} \mathrm{C}$ along on the Red Sea coastline. The difference between the values of mean temperature in the north and the south of Egypt reaches about $6^{\circ} \mathrm{C}$ in autumn. Also, annual mean temperature has minimum value of $20.5^{\circ} \mathrm{C}$ at the Mediterranean coastline and maximum value of $27^{\circ} \mathrm{C}$ south at Aswan. The difference between the values of mean annual temperature in the north and the south of Egypt is about $7.5^{\circ} \mathrm{C}$.

\subsection{Trend analysis}

\subsubsection{Monthly Temperature Trend}

The results obtained from the trend values of the monthly temperature of Egypt stations by least square method over the analyzed period (1960-2016) is shown in figure 6. It is clear that a general dominating positive temperature trend over Egypt and trend values increase gradually from north to south Egypt with rate of change varying from 0.09 to $0.48{ }^{\circ} \mathrm{C} /$ month. Where the higher rate of change occurs at South East of Egypt by about $0.48{ }^{\circ} \mathrm{C} /$ month but lower rate of change occurs at North West of Egypt and North East of Sinai by about $0.09^{\circ} \mathrm{C} /$ month.

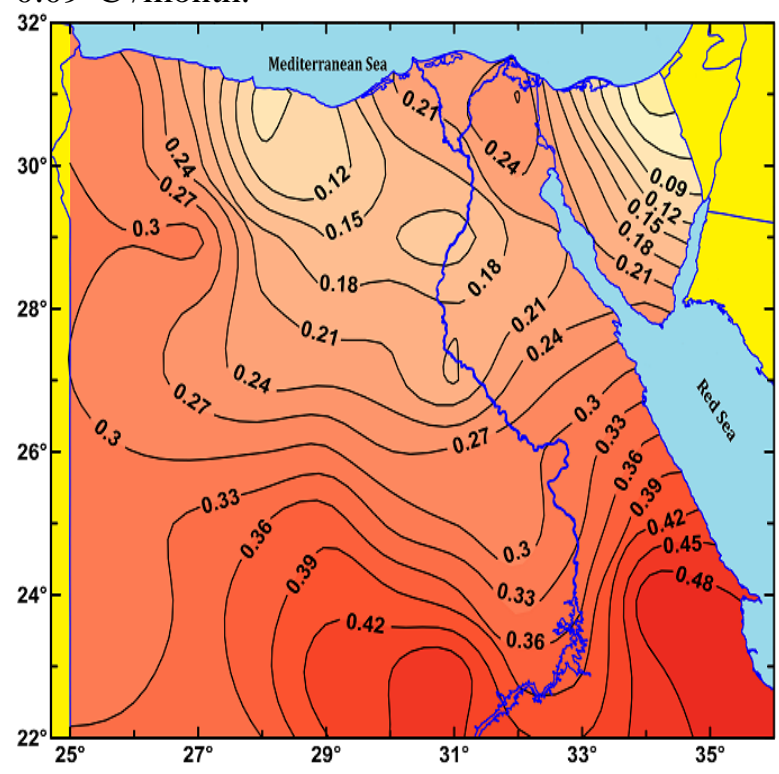

Fig. 6: The trend values of the monthly temperature of Egypt stations by least square method.

This indicates that the warm trend occurs generally in South of Egypt, while the cold trend occurs generally in north of Egypt compared to warm trend in south. Relative cooling trend in the north is due to the Mediterranean depressions accompanying the northern wind in most time of the year, while the warm trend in the south is due to Sudan monsoon low, which is accompanied by hot south-eastern wind most time of the year. Where the Sudan monsoon low intensifies towards the north and supplies the eastern Egypt with a warm south-easterly wind in many cases.

\subsubsection{Seasonal and Annual Temperature Trends}

Mann Kendall test is a statistical test widely used for the analysis of trend in climatologic and in hydrologic time series. There are two advantages of using this test. First, it is a non-parametric test and does not require the data to be normally distributed. Second, the test has low sensitivity to abrupt breaks due to inhomogeneous time series. Table 3 shows the $\mathrm{M}-\mathrm{K}$ statistics for study stations in Egypt for winter, spring, summer, autumn seasons and annual of mean temperature during the period 1960-2016. In winter season the mean temperature shows an increasing trend for all stations except El- Arish 
and Asyut Ap. Also, in winter season the mean temperature is statistically significant at $95 \%$ confidence level for all stations except MersaMatruh, Alexandria, Helwan, Beni Suef, Baharia and Aswan stations.

Table 3. Mann-Kendall trend of seasonal and annual mean temperature for study stations over Egypt.

\begin{tabular}{|c|c|c|c|c|c|c|}
\hline \multirow{2}{*}{ No } & \multirow{2}{*}{$\begin{array}{c}\text { Station } \\
\text { name }\end{array}$} & \multicolumn{5}{|c|}{ Trend 57 year length } \\
\hline & & Win & Spr & Sum & Aut & $\mathbf{Y r}$ \\
\hline 1 & Baltim & $0.49^{*}$ & $0.27^{*}$ & $0.45^{*}$ & $0.49^{*}$ & $0.50^{*}$ \\
\hline 2 & Port Said & $0.30^{*}$ & $0.24^{*}$ & $0.40^{*}$ & $0.38^{*}$ & $0.31^{*}$ \\
\hline 3 & $\begin{array}{l}\text { Mersa- } \\
\text { Matruh }\end{array}$ & $0.32^{* * *}$ & $0.20^{*}$ & $0.35^{*}$ & $0.46^{*}$ & $0.46^{*}$ \\
\hline 4 & Alexandria & $0.21^{* * *}$ & $0.24^{*}$ & $0.48^{*}$ & $0.38^{*}$ & $0.42^{*}$ \\
\hline 5 & $\begin{array}{l}\text { El Arish } \\
\text { Ap }\end{array}$ & $-0.30^{*}$ & $-0.12^{*}$ & $0.24^{*}$ & $0.04^{*}$ & $\overline{-}^{-}$ \\
\hline 6 & Tanta & $0.22^{*}$ & $0.20^{*}$ & $0.32^{*}$ & $0.32^{*}$ & $0.25^{*}$ \\
\hline 7 & Tahrir & $0.31^{*}$ & $0.24^{*}$ & $0.36^{*}$ & $0.34^{*}$ & $0.33^{*}$ \\
\hline 8 & $\begin{array}{l}\text { Ismailia } \\
\text { AP }\end{array}$ & $0.32^{*}$ & $0.37^{*}$ & $0.55^{*}$ & $0.43^{*}$ & $0.46^{*}$ \\
\hline 9 & Dabaa & $0.18^{*}$ & $-0.10^{*}$ & $-0.04^{*}$ & $0.14^{*}$ & $0.01^{*}$ \\
\hline 10 & $\begin{array}{l}\text { Wadi- } \\
\text { Elnatroon }\end{array}$ & $0.35^{*}$ & $0.14^{*}$ & $0.30^{*}$ & $0.30^{*}$ & $0.35^{*}$ \\
\hline 11 & Cairo AP & $0.30^{*}$ & $0.30^{*}$ & $0.56^{*}$ & $0.44^{*}$ & $0.48^{*}$ \\
\hline 12 & El-Suez & $0.19^{*}$ & $0.22^{* * *}$ & $0.48^{*}$ & $0.32^{*}$ & $0.36^{*}$ \\
\hline 13 & Helwan & $0.12^{* * *}$ & $0.15^{*}$ & $0.41^{*}$ & $0.28^{* * *}$ & $0.33^{*}$ \\
\hline 14 & Ras-Sedr & $0.23^{*}$ & $0.21^{*}$ & $0.48^{*}$ & $0.37^{*}$ & $0.40^{*}$ \\
\hline 15 & $\begin{array}{l}\text { Ras- } \\
\text { Elnakab }\end{array}$ & $0.04^{*}$ & $0.09^{* *}$ & $0.35^{*}$ & $0.15^{* *}$ & $0.19^{*}$ \\
\hline 16 & Beni Suef & $0.13^{* *}$ & $0.14^{* * *}$ & $0.42^{*}$ & $0.22^{* *}$ & $0.29^{*}$ \\
\hline 17 & Siwa & $0.45^{*}$ & $0.39^{* * *}$ & $0.46^{*}$ & $0.46^{*}$ & $0.58^{*}$ \\
\hline 18 & Baharia & $0.27^{* * *}$ & $0.22^{* * *}$ & $0.38^{*}$ & $0.29^{* * *}$ & $0.39^{*}$ \\
\hline 19 & El-Tor & $0.45^{*}$ & $0.23^{\text {*** }}$ & $-0.01^{*}$ & $0.46^{*}$ & $0.47^{*}$ \\
\hline 20 & Minya & $0.25^{*}$ & $0.18^{*}$ & $0.48^{*}$ & $0.38^{*}$ & $0.41^{*}$ \\
\hline 21 & $\begin{array}{l}\text { Sharm El- } \\
\text { Sheikh }\end{array}$ & $0.42^{*}$ & $0.08^{*}$ & $0.28^{*}$ & $0.34^{*}$ & $0.27^{*}$ \\
\hline 22 & Hurghada & $0.15^{*}$ & $0.24^{* * *}$ & $0.50^{*}$ & $0.25^{* * *}$ & $0.40^{*}$ \\
\hline 23 & $\begin{array}{l}\text { Hurghada } \\
\text { AP }\end{array}$ & $0.47^{*}$ & $0.17^{*}$ & $0.42^{*}$ & $0.42^{*}$ & $0.54^{*}$ \\
\hline 24 & Farafra & $0.32 *$ & $0.22^{*}$ & $0.45^{*}$ & $0.32^{* *}$ & $0.51^{*}$ \\
\hline 25 & Asyut AP & $-0.01^{*}$ & $0.17^{*}$ & $0.47^{*}$ & $0.17^{*}$ & $0.25^{*}$ \\
\hline 26 & Sohag & $0.29^{*}$ & $0.46^{*}$ & $0.59^{*}$ & $0.37^{* * *}$ & $0.55^{*}$ \\
\hline 27 & Luxor & $0.29^{*}$ & $0.36^{* *}$ & $0.54^{*}$ & $0.30^{* *}$ & $0.47^{*}$ \\
\hline 28 & $\begin{array}{l}\text { Al-Kharga } \\
\text { (Ag) }\end{array}$ & $0.34^{*}$ & $0.27^{*}$ & $0.51^{* *}$ & $0.38^{* * *}$ & $0.52^{*}$ \\
\hline 29 & Al-Dakhla & $0.48^{*}$ & $0.41^{*}$ & $0.52^{*}$ & $0.51^{*}$ & $0.62 *$ \\
\hline 30 & Aswan & $0.27^{* *}$ & $0.40^{*}$ & $0.56^{*}$ & $0.37^{* *}$ & $0.52 *$ \\
\hline
\end{tabular}

* Significant at $95 \%$ confidence level.

** Non-Significant at $\mathbf{9 5 \%}$ confidence level

In spring season it is noted that the mean temperature shows an increasing trend for all stations except El-Arish AP and Dabaa, significant trend for all stations except El-Suez, Ras-Elnakab, Beni Suef, Siwa, Baharia, El-Tor, Hurghada and Luxor stations. In summer season the mean temperature also shows an increasing trend for all stations except El-Tor and Dabaa stations have a negative trend, significant at $\mathrm{P}<0.05$ level for all stations except Kharga (Ag) station. In autumn season the mean temperature shows an increasing trend for all stations, significant trend for all stations except Helwan, Ras- Elnakab, Beni Suef, Baharia, Hurghada, Sohag, Luxor, Kharga (Ag), Farafra and Aswan stations. The MannKendall test of the mean annual temperature confirmed that the positive trend (warming) for all stations except El Arish AP, Also, trend is significant at $95 \%$ confidence level for study stations over Egypt.

\subsection{Coefficient of variation}

In order to obtain a clear and representative analysis of temperature in Egypt, the COV is adopted to assess the durability and stability of the temperature regime at all Egyptian stations. The COV is a good way to evaluate variability of temperature. Also, the COV offers an indication of the reliability of the average. The higher the COV, the less reliable the average is; and the lower the COV, the more dependable the average is.

Figure 7 shows the Coefficient of variation's distribution of winter, spring, summer, autumn and annual temperature over Egypt. Generally, it is clear that COV values of winter temperature are greater than those corresponding to summer, spring, autumn and annual values. Therefore, the winter temperature is less stable than the other seasons over Egypt. Generally the winter temperature COV increases gradually from north to south of Egypt. The higher values of COV occur at southwest of Egypt especially over the western desert region then Al-kharga and Al-Dakhla stations. The lower values of the COV of winter occur at the northwest of Egypt. It is clear that $\mathrm{COV}$ values increase gradually from south to north along the edge Red Sea coastline. It is clear that high variability of $\mathrm{COV}$ in spring temperature is observed over the north western and middle area of Egypt (Mersa-Matruh, Dabaa, Tanta, Tahrir, Ismailia AP, Wadi-Elnatroon, Cairo AP, Ras-Sedr, RasElnakab and Beni Suef. It is clear that the low values of $\mathrm{COV}$ in spring temperature appear in the south of Egypt. It is clear that the values of summer temperature COV generally decrease from the north of Egypt to the south of Egypt. The values of summer temperature $\mathrm{COV}$ are lower than those corresponding to the other seasons. Therefore, the summer temperature is more stable than the other seasons over Egypt. 
The highest values are observed over the north of Egypt, while the lowest values are observed over south east of Egypt. Summer COV values range from $3.2 \%$ at north stations to $2.3 \%$ at south stations. The COV values for autumn temperature are displayed and it is clear that the $\mathrm{COV}$ varies from area to area, where high values are observed over the south west area, especially in Asyut AP, Souhag, Al-Dakhla and Al-Kharga and COV values reaches about $4.7 \%$

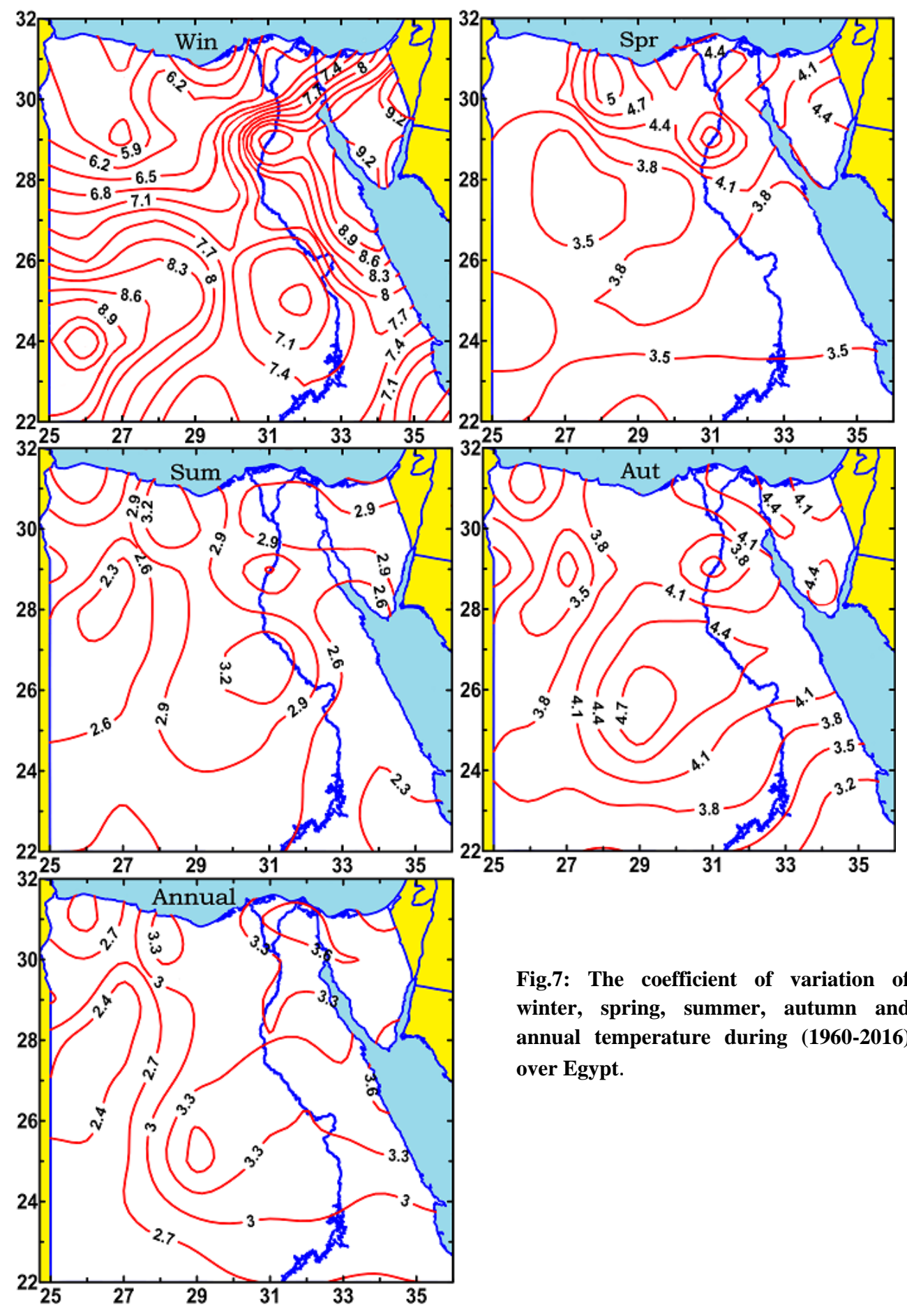




\subsection{Spatial distribution of monthly temperature.}

Figures $8 \mathrm{a}$ and $8 \mathrm{~b}$ show the spatial distribution of temperature average (1960 2016) for each month of the year using NCEP/NCAR Reanalysis data. The main results from these two figures can be summarized as follows:

- The lowest temperature values occur north of $25^{\circ} \mathrm{N}$ during the winter and spring months while the highest temperature values occur in the south and southeast of Egypt.

- Generally, temperature is seen to increase gradually with latitude from north to south. Latitudinal gradients of temperature are strong in winter and spring months, especially north of $20^{\circ} \mathrm{N}$. Latitudinal gradients in winter and spring months are around 2-3 times larger than those of the summer and autumn months. Despite the difference in latitudinal gradient in temperature, the region south of $20^{\circ} \mathrm{N}$ exhibits a small gradient of temperature in winter and spring months.

- With the beginning of May the values of temperature start increasing gradually from south to north where we found that the values in the middle and south of Egypt are greater than those of the previous months. This situation pertains also in June.

- The highest values of temperature in winter and spring months occur in the south, especially in the southeast of Egypt. The difference between the values of temperature in the north and the south of Egypt reaches $9{ }^{\circ} \mathrm{C}$ in summer and $8{ }^{\circ} \mathrm{C}$ in spring.

- The effect of the Red Sea and the Red Sea trough can be detected from the distribution of temperature over the Red Sea throughout the months of the year. The climatological distribution of temperature throughout the months of the year reflects the effect of meteorological factors and pressure systems affecting the weather and climate of our area. The strong latitudinal gradient of temperature with the increase of its quantity over the north of Egypt in winter and spring is due to midlatitude traveling depressions from west to east that affects the weather during this time.

- Fig. 8a and 8b also show that the Sudan low is associated with temperature above $30{ }^{\circ} \mathrm{C}$ during the transitional seasons.
- In the summer, the temperature of the middle and Eastern part of Egypt changes in association with the west- east movement of the Indian Monsoon low.

The synoptic circulation over Egypt is complicated and is the result of a combination of different pressure systems. The spatial distribution of surface temperature throughout the months of the year is associated with mean sea level pressure. So, the monthly temperature of any area is associated with the dominant pressure systems affecting the weather and climate of that area. The dominant pressure systems affecting the climate of Egypt are the Siberian high, the Sub-tropical high, the easterly trough which is an extension of the Indian Monsoon low, and the Red Sea trough which is the extension of the Sudan Monsoon low. Now we will illustrate the monthly spatial distribution of temperature in association with the movement and oscillation of these pressure systems during the months of the year. The Red sea trough is considered as an extension of the Sudan low. So, the northward or southward oscillation of the Red sea trough arises from the northward or southward oscillations of the Sudan low. The mean position of the Sudan low has changed from season to season; these changes in the mean position of the low are also dynamical [37]. In other words, they are not only due to thermal effects between land and sea, but also due to the general wind system. In autumn they cause the spreading out of heat waves and thundery conditions over the northeast areas of its center of action. (ElFandy, 1948) provides a nice illustration of how the so-called small oscillations accompany the passage of troughs of low pressure, or secondaries, associated with depressions traveling further north and east over the Eastern Mediterranean, Eastern Europe and eastern part of Arabian Peninsula. The Siberian high (in winter) is centered over Kazakhstan with a maximum pressure of more than $1028 \mathrm{hPa}$ over $\left(47^{\circ} \mathrm{N}, 70^{\circ} \mathrm{E}\right)$. Its south extension covers north east Africa and the east Mediterranean and brings cold air to this area. The minimum temperature at its center is $-5^{\circ} \mathrm{C}$. The situation of the Siberian high in spring is somewhat like that during winter, but actually the Siberian high becomes weakened and its center moves north eastward. During summer more weakening and north east movement of the 
Siberian high occurs, which is associated with an increase of temperature in the areas of retreat.

In autumn the Siberian high builds, up and moves gradually south westward. Its maximum pressure appears at $\left(46^{\circ} \mathrm{N}, 68^{\circ} \mathrm{E}\right)$ and is more than $1022 \mathrm{hPa}$. This situation is associated with a decrease of temperature and relative humidity over the area covered by the Siberian high. The movement and oscillation of the surface subtropical high is associated with the movement and oscillation of the Siberian high. It can be noticed that when the Siberian high moves north eastward the subtropical high
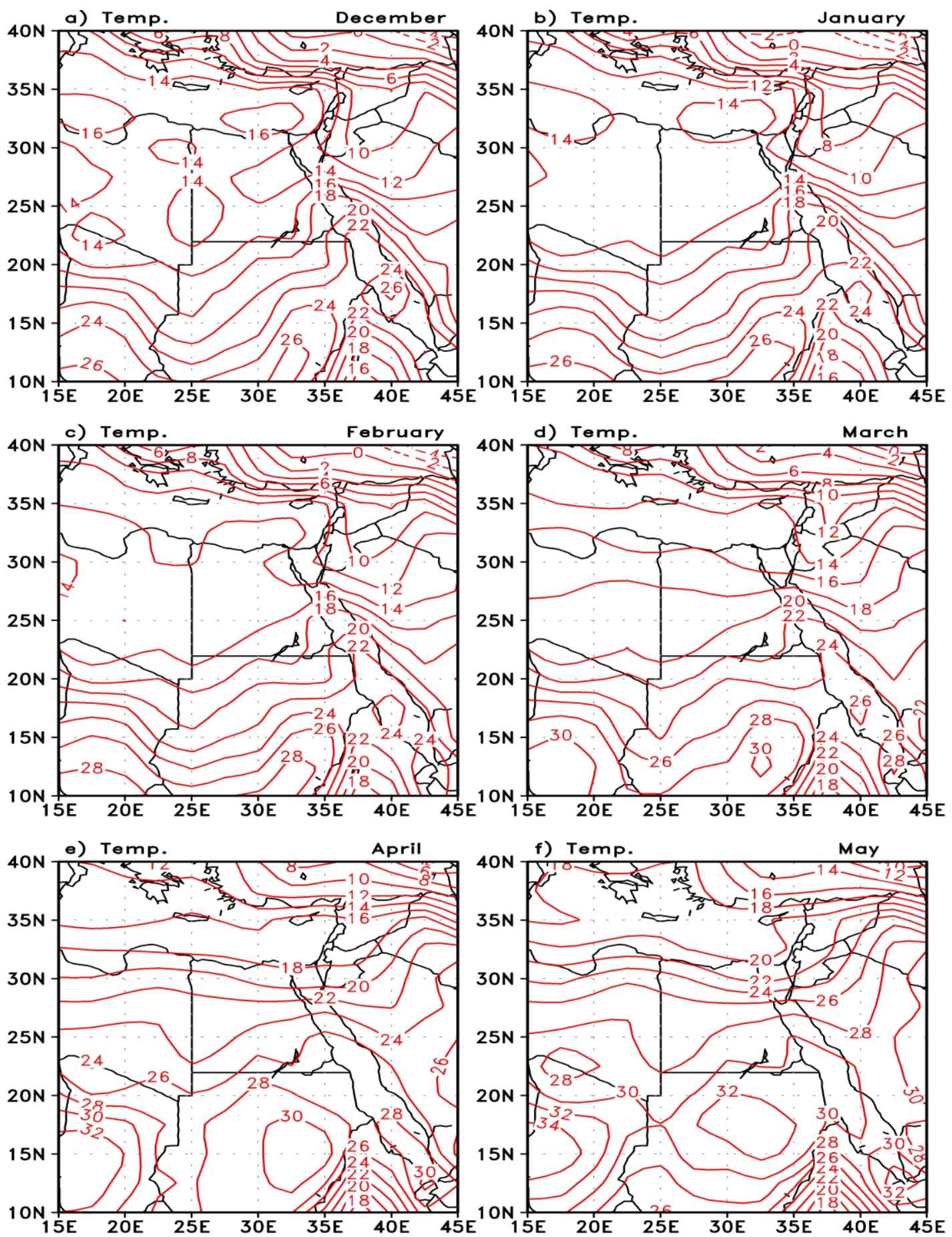

Fig. 8a: The spatial distribution of the monthly means temperature average along the period (19602016) in ${ }^{\circ} \mathrm{C}$ during winter and spring months (December to May) 
moves and extends eastward reaching north east Africa and the east Mediterranean. This situation occurs during the summer season. On the other hand, during the winter season the surface subtropical high moves westward and our area is affected by this extension.

The Indian monsoon low may be considered as being one of the most important systems affecting the weather of Egypt. We will introduce firstly the Monsoon circulation and secondly the Asian (Indian) Monsoon. The prime cause of Monsoon circulation is the thermal direct cell resulting from surface temperature differences between ocean and land. This type of circulation can only become
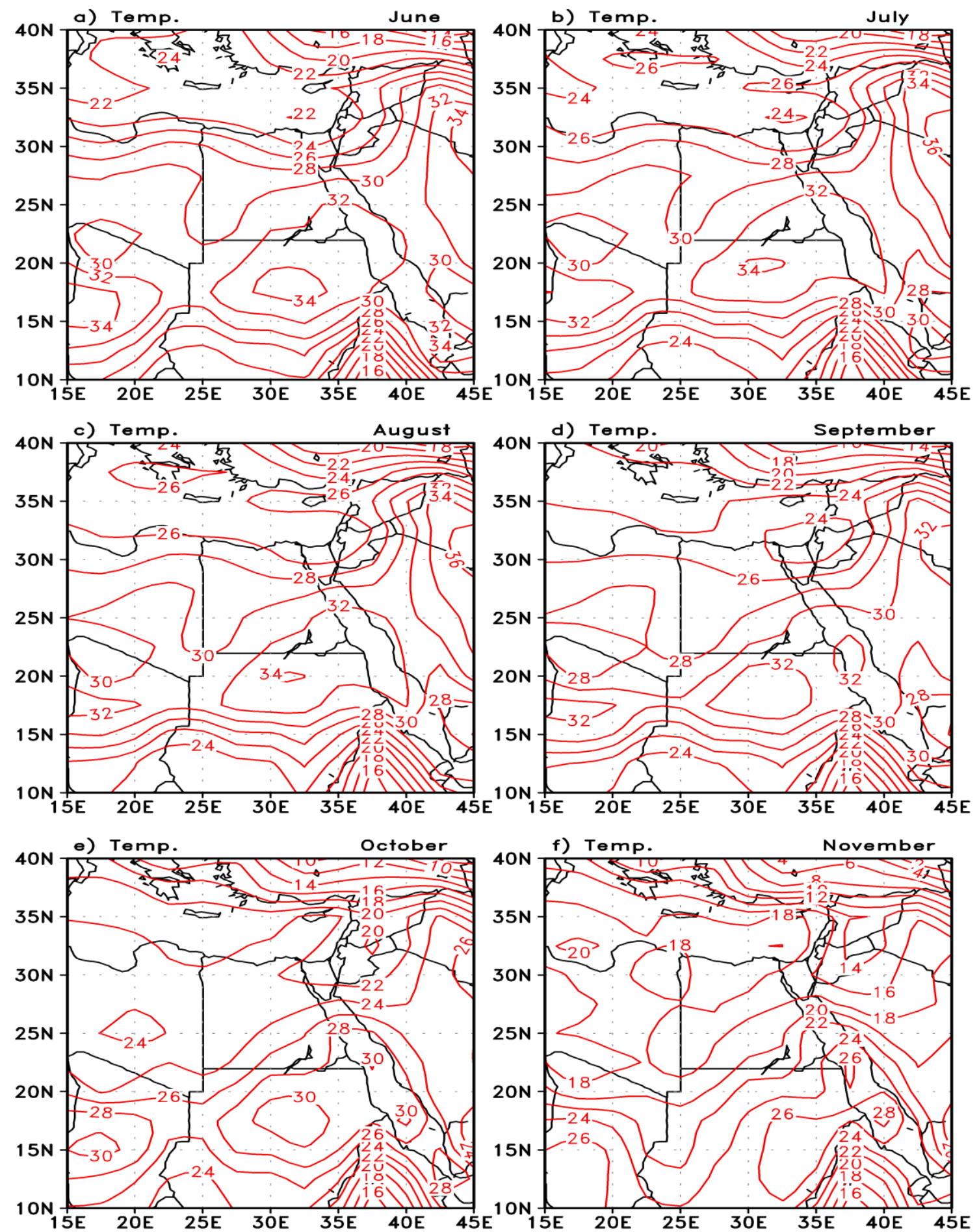

Fig. 8b: Same as in Fig. 8a but for summer and autumn months (June to November). 
well established in approximately barotropic conditions and where there is a favorable distribution of land and sea. Thus, although a summer monsoon type circulation will develop over most tropical regions in most of those areas, the circulation is overshadowed by other features and may not be accompanied by the necessary winter time reversal of wind direction, which is required for a true monsoon regime. In general, it is only the continent of Asia that displays large areas of monsoon climate.

The Indian monsoon is itself a result of a complex interaction between the distribution of land and water, topography and tropical and mid-latitude circulations. It is the simplest model which is a good first approximation to the summer circulation pattern, with low pressure centers over the northern part of the Indian sub-continent and northern Southeast Asia. Warm moist air is drawn into the thermally created low pressure areas of the continental interior, where it rises releasing both precipitations, to create the wet season, and latent heat to provide the energy necessary to continue the system over the ocean and compensating for the descent of cold dry air. Once this pattern is established, the on-shore winds bring the monsoon rains. The moisture laden winds are highly susceptible to orographic influences, so that the coastlands of India for example, which are backed by mountain ranges, receive the most rainfall. The interior of course also receives rain, since the whole area is one of rising air. The Himalayas effectively provide a barrier to the north, confining the circulation to the area south of this mountain chain [39].

\section{CONCLUSION}

The temperature analysis and variability have been studied in this paper. It is found that the temperature is a function of latitude where it increases gradually from north to south of Egypt. The annual cycle is the dominant feature at all stations. Its amplitude for the northern stations is smaller than those for the southern stations. The range between the monthly values of the northern stations $\left(20^{\circ} \mathrm{C}\right)$ is smaller than that in the southern stations $\left(25^{\circ} \mathrm{C}\right)$. Minimum values of temperatures are relatively more frequent at all stations in the years of 1967, 1983 and 1989. Similarly but for a different attribute, a relatively more occurrences of maximum values of temperature at most stations have been observed in the years of 2010, 2014 and 2016.

The analyses of the monthly temperature for the Egypt stations indicate that the values of temperature start to increase gradually from March to reach the maximum in July. The values then decrease gradually to the minimum values in December. The difference between the average values of some months in the southern stations and in the northern stations is recorded as high as $10^{\circ} \mathrm{C}$.

An evaluation of the spatial distribution of the monthly average of temperature (1960 2016) for each month has also been undertaken. Generally, it is found that the temperature is seen to increase with latitude. Latitudinal gradients in temperature are strong in winter and spring seasons, especially towards the north of latitude $20^{\circ} \mathrm{N}$. Latitudinal gradients in winter and spring seasons are 2-3 times much stronger than during the summer and autumn seasons. The highest values of temperature in winter and spring seasons occur in the south, especially in the southeast of Egypt. The difference between the values of temperature in the north and the south of Egypt are measured at $5^{\circ} \mathrm{C}$ and $8^{\circ} \mathrm{C}$ during the winter and spring respectively.

The effect of the Red Sea and Red Sea troughs can be detected from the distribution of temperature over the Red Sea throughout the year. The climatological distribution of temperature throughout the year reflects the effect of meteorological factors and pressure systems affecting the weather and climate in the studied region. The strong latitudinal gradient of temperature, with particular increase over the north of Egypt in winter and spring, is generated by the mid-latitude travelling depressions from west to east that 
affect the weather during this period. In the summer the warmest areas of Egypt are the middle and the southern parts of the eastern section.

\section{REFERENCES}

[1] Vinnikov KY, Groisman PY, Lugina KM. Empirical data on contemporary global climate changes (temperature and precipitation). Journal of Climate. 1990 Jun;3(6):662-77.

[2] Folland CK, Karl TR, Christy JR, Clarke RA, Gruza GV, Jouzel J, Mann ME, Oerlemans J, Salinger MJ, Wang SW. Observed climate variability and change. Climate change. 2001;2001:99.

[3] Trenberth KE, Fasullo JT. An apparent hiatus in global warming?. Earth's Future. 2013 Dec;1(1):19-32.

[4] IPCC. The Physical Science Basis. Contribution of Working Group I to the Fifth Assessment Report of the Intergovernmental Panel on Climate Change,Stocker TF, Qin D, Plattner GK, Tignor M, Allen SK, Boschung J, Nauels A, Xia Y, Bex V, Midgley PM. Climate change 2013: The physical science basis.

[5] Paeth H, Born K, Girmes R, Podzun R, Jacob D. Regional climate change in tropical and northern Africa due to greenhouse forcing and land use changes. Journal of Climate. 2009 Jan;22(1):114-32.

[6] Fontaine B, Janicot S, Monerie PA. Recent changes in air temperature, heat waves occurrences, and atmospheric circulation in Northern Africa. Journal of Geophysical Research: Atmospheres. 2013 Aug 16;118(15):8536-52.

[7] El Kenawy A, López-Moreno JI, McCabe MF, Brunsell NA, Vicente-Serrano SM. Daily temperature changes and variability in ENSEMBLES regional models predictions: Evaluation and intercomparison for the Ebro Valley (NE Iberia). Atmospheric Research. 2015 Mar 15;155:141-57.

[8] Hasanean HM. Wintertime surface temperature in Egypt in relation to the associated atmospheric circulation. International Journal of Climatology: A Journal of the Royal Meteorological Society. 2004 Jun 30;24(8):98599.

[9] Domroes M, El-Tantawi A. Recent temporal and spatial temperature changes in Egypt. International Journal of Climatology: A Journal of the Royal Meteorological Society. 2005 Jan;25(1):51-63.
[10] Hasanean HM, Basset HA. Variability of summer temperature over Egypt. International Journal of Climatology: A Journal of the Royal Meteorological Society. 2006 Oct;26(12):161934.

[11] El Kenawy AM, Lopez-Moreno JI, VicenteSerrano SM, Mekld MS. Temperature trends in Libya over the second half of the 20th century. Theoretical and applied climatology. 2009 Sep $1 ; 98(1-2): 1-8$.

[12] El Kenawy A, López-Moreno J, VicenteSerrano S, Abdelal M. Temperature variability along the Mediterranean and its links to largescale atmospheric circulation (1957-2006). Bull Egypt Geogr Soc. 2010;83:121-40.

[13] Nazrul Islam M, Almazroui M, Dambul R, Jones PD, Alamoudi AO. Long-term changes in seasonal temperature extremes over Saudi Arabia during 1981-2010. International Journal of Climatology. 2015 Jun 15;35(7):1579-92.

[14] Khomsi K, Mahe G, Tramblay Y, Sinan M, Snoussi M. Regional impacts of global change: seasonal trends in extreme rainfall, run-off and temperature in two contrasting regions of Morocco. Natural Hazards and Earth System Sciences. 2016 May 10;16(5):1079-90.

[15] Kostopoulou E, Jones PD. Assessment of climate extremes in the Eastern Mediterranean. Meteorology and Atmospheric Physics. 2005 Jun 1;89(1-4):69-85.

[16] Hertig E, Seubert S, Jacobeit J. Temperature extremes in the Mediterranean area: trends in the past and assessments for the future. Natural Hazards and Earth System Sciences. 2010 Oct 5;10(10):2039-50.

[17] Harpaz T, Ziv B, Saaroni H, Beja E. Extreme summer temperatures in the East Mediterranean-dynamical analysis. International Journal of Climatology. 2014 Mar 15;34(3):849-62.

[18] Zhang X, Aguilar E, Sensoy S, Melkonyan H, Tagiyeva U, Ahmed N, Kutaladze N, Rahimzadeh F, Taghipour A, Hantosh TH, Albert P. Trends in Middle East climate extreme indices from 1950 to 2003. Journal of Geophysical Research: Atmospheres. 2005 Nov 27;110(D22).

[19] Donat MG, Peterson TC, Brunet M, King AD, Almazroui M, Kolli RK, Boucherf D, Al-Mulla AY, Nour AY, Aly AA, Nada TA. Changes in extreme temperature and precipitation in the Arab region: long-term trends and variability related to ENSO and NAO. International 
Journal of Climatology. 2014 Mar 15;34(3):581-92.

[20] Karl TR, Knight RW, Plummer N. Trends in high-frequency climate variability in the twentieth century. Nature. 1995 Sep;377(6546):217.

[21] Alexander LV, Zhang X, Peterson TC, Caesar J, Gleason B, Klein Tank AM, Haylock M, Collins D, Trewin B, Rahimzadeh F, Tagipour A. Global observed changes in daily climate extremes of temperature and precipitation. Journal of Geophysical Research: Atmospheres. 2006 Mar 16;111(D5).

[22] Rahimi M, Mohammadian N, Vanashi AR, Whan K. Trends in Indices of Extreme Temperature and Precipitation in Iran over the Period 1960-2014. Open Journal of Ecology. 2018 Jul 16;8(07):396.

[23] Salman SA, Shahid S, Ismail T, Chung ES, AlAbadi AM. Long-term trends in daily temperature extremes in Iraq. Atmospheric research. 2017 Dec 1;198:97-107.

[24] Almazroui M, Islam MN, Dambul R, Jones PD. Trends of temperature extremes in Saudi Arabia. International Journal of Climatology. 2014 Mar 15;34(3):808-26.

[25] Freiwan M, Kadioğlu M. Climate variability in Jordan. International Journal of Climatology: A Journal of the Royal Meteorological Society. 2008 Jan;28(1):69-89.

[26] Herring SC, Hoerling MP, Peterson TC, Stott PA. Explaining extreme events of 2013 from a climate perspective. Bulletin of the American Meteorological Society. 2014 Sep;95(9):S1-04.

[27] Mitchell D. Human influences on heat-related health indicators during the 2015 Egyptian heat wave. Bulletin of the American Meteorological Society. 2016 Dec;97(12):S70-4.

[28] Ceccherini G, Russo S, Ameztoy I, Marchese AF, Carmona-Moreno C. Heat waves in Africa 1981-2015, observations and reanalysis. Natural Hazards and Earth System Sciences. 2017 Jan 30;17(1):115-25.

[29] Abutaleb KA, Mohammed AH, Ahmed MH. Climate change impacts, vulnerabilities and adaption measures for Egypt's nile delta. Earth Systems and Environment. 2018 Oct 1;2(2):183-92.

[30] Mitchell JM, Dzerdzeevskii B, Flohn H, Hofmeyr WL, Lamb HH, Rao KN, Wallén CC. Climatic change. Technical Note, No. 79. World Meteorological Organization: Geneva, Switzerland. 1966;99.
[31] Pearson ES, Hartley HO. Test for heterogeneity of variance among normally distributed observations. Biometrika tables for statisticians. Vol. I. 1958:57-61.

[32] Kalnay E, Kanamitsu M, Kistler R, Collins W, Deaven D, Gandin L, Iredell M, Saha S, White G, Woollen J, Zhu Y. The NCEP/NCAR 40year reanalysis project. Bulletin of the American meteorological Society. 1996 Mar;77(3):437-72.

[33] Kistler R, Kalnay E, Collins W, Saha S, White G, Woollen J, Chelliah M, Ebisuzaki W, Kanamitsu M, Kousky V, van den Dool H. The NCEP-NCAR 50-year reanalysis: monthly means CD-ROM and documentation. Bulletin of the American Meteorological society. 2001 Feb;82(2):247-68.

[34] Solomon S, Qin D, Manning M, Averyt K, Marquis M, Tignor MM, editors. Climate change 2007-the physical science basis: Working group I contribution to the fourth assessment report of the IPCC. Cambridge university press; 2007 Sep 10.

[35] Thomson DJ. The seasons, global temperature, and precession. Science. $1995 \mathrm{Apr}$ 7;268(5207):59-68.

[36] Jones PD, Briffa KR, Osborn TJ. Changes in the Northern Hemisphere annual cycle: Implications for paleoclimatology?. Journal of Geophysical Research: Atmospheres. 2003 Sep 27;108(D18).

[37] El-Fandy MG. The formation of depressions of khamsin type. Bulletin of the American Meteorological Society. 1940 Dec;31(10):37581.

[38] El-Fandy MG. The effect of the sudan monsoon low on the development of thundery conditions in Egpyt, Palestine and Syria. Quarterly Journal of the Royal Meteorological Society. 1948 Jan;74(319):31-8.

[39] Ramage, C.S. (1971) Monsoon Meteorology. Academic Press, New York, 296 p. 


\section{تحليل درجة الحرارة فوق مصر \\ د/ محمد عيد محروس و السعيد حسن جاد و ا.د/ حشمت عبدالباسط محمد \\ قسم الفلك والأرصاد الجوية ـ كلية العلوم (بنين) - جامعة الأزهر - القاهره ـ مصر}

\section{الملخص}

في هذا البحث تم تحليل قيم درجات الحرارة الثـهرية والفصلية والسنوية فوق مصر خـلال الفتره (1960-2016). وقد وجد أن التغير في درجة الحرارة دالـة في دوائر العرض، حيث تزدداد قيم

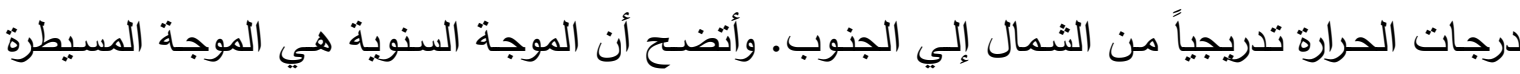

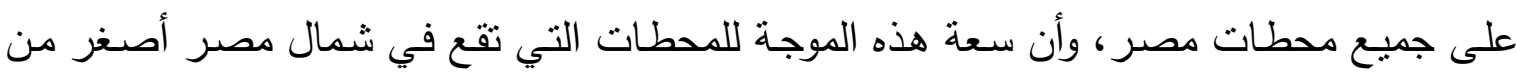
تلالك التي بجنوبها. وقد تم أيضا في هذا البحث تحليل التوزيع المكاني الأفقي لمتوسط درجات الحرارة

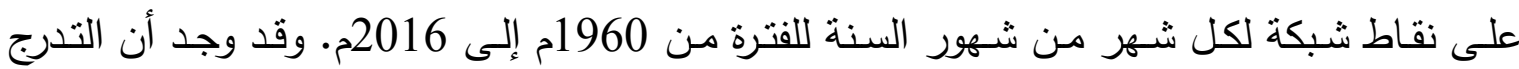

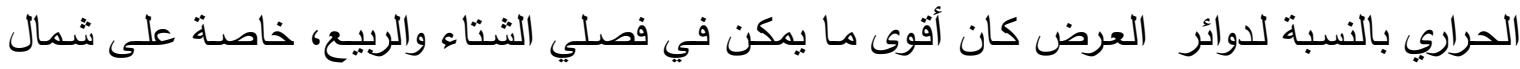
مصر نتيجة لمرور المنخفضات السيارة من الغرب إلي الثرق، والتي تؤثر على طقس مصر في هذه لأه

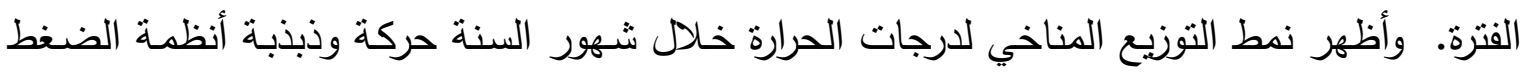

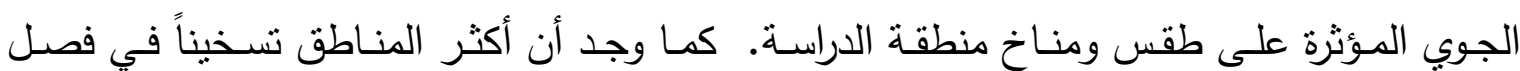
الصيف المنطقة الوسطي والجنوبية الثرقية من مصر . 